\title{
Nieuw onderzoek naar plasma-antistofbehandeling voor niet-opgenomen COVID-19-patiënten
}

Bart Rijnders

De mortaliteit van de in het ziekenhuis opgenomen COVID-19-patiënten is 10-15\%. Recent onderzoek toont aan dat monoclonale antistofbehandeling in de eerste week van ziekte het aantal ziekenhuisopnames drastisch vermindert. Deze behandeling is duur en de productie is niet snel opschaalbaar. Bloedplasma van donoren die worden geselecteerd aan de hand van de hoeveelheid en de antivirale eigenschappen van hun antistoffen zou eenzelfde gunstig effect kunnen bewerkstelligen. In de CoV-Early-studie wordt dit onderzocht. Huisartsen kunnen patiënten die hiervoor in aanmerking komen op dit onderzoek wijzen.

Met gebruik van in vitro gekweekt SARS-CoV-2 is het mogelijk plasmadonoren te identificeren die veel en sterk virusneutraliserende antistoffen produceren. Dit plasma heeft de potentie om een behandeling voor COVID-19 te zijn voor patiënten die nog weinig of geen antistoffen aanmaken en nog niet heel ziek zijn. Uit Nederlands en ander onderzoek weten we dat antistofbehandeling geen nut heeft wanneer het pas wordt gegeven op het moment dat ziekenhuisopname nodig is. ${ }^{1-3}$ De meeste patiënten maken dan namelijk zelf al grote hoeveelheden antistoffen aan. In 2 recente onderzoeken werden patiënten in de eerste 7 dagen van ziekte met een monoclonale antistof (bamlinivumab of Regn-Cov2) behandeld. Daarbij bleek het aantal ziekenhuisopnames bij risicopatiënten met $>50 \%$ te dalen. ${ }^{4}$ We hopen in de CoV-Early-studie eenzelfde effect te bewijzen met gebruik van convalescent plasma. De bloedbank heeft de voorbije 8 maanden duizenden liters plasma verzameld van genezen COVID-19-patiënten. Bewezen effectiviteit van plasma zou dus een onmiddellijk inzetbare behandeling tot gevolg hebben.

Om de effectiviteit van een behandeling te kunnen aantonen is het noodzakelijk om deze te testen bij patiënten van wie kan worden verwacht dat ze er het meeste baat bij hebben. Dat zijn patiënten die een verhoogd risico hebben op een ernstig beloop van COVID-19 (langdurige ziekte, ziekenhuisopname of overlijden). De CoV-Early-studie heeft als doel te bewijzen dat een behandeling met convalescent plasma de kans op ziekenhuisopname of overlijden verkleint en de duur van ziekte door COVID-19 verkort.

Het onderzoek wordt gecoördineerd door het Erasmus MC en het LUMC, de bloedbank Sanquin levert het plasma. ZonMw en het ministerie van VWS maken het onderzoek financieel mogelijk.

De eerste 40 patiënten werden vanaf begin november 2020 geïncludeerd in de eerste 3 ziekenhuizen die voor dit onderzoek zijn toegerust (Erasmus MC Rotterdam, Groene Hart Ziekenhuis Gouda en LUMC Leiden). Twaalf andere zieken-

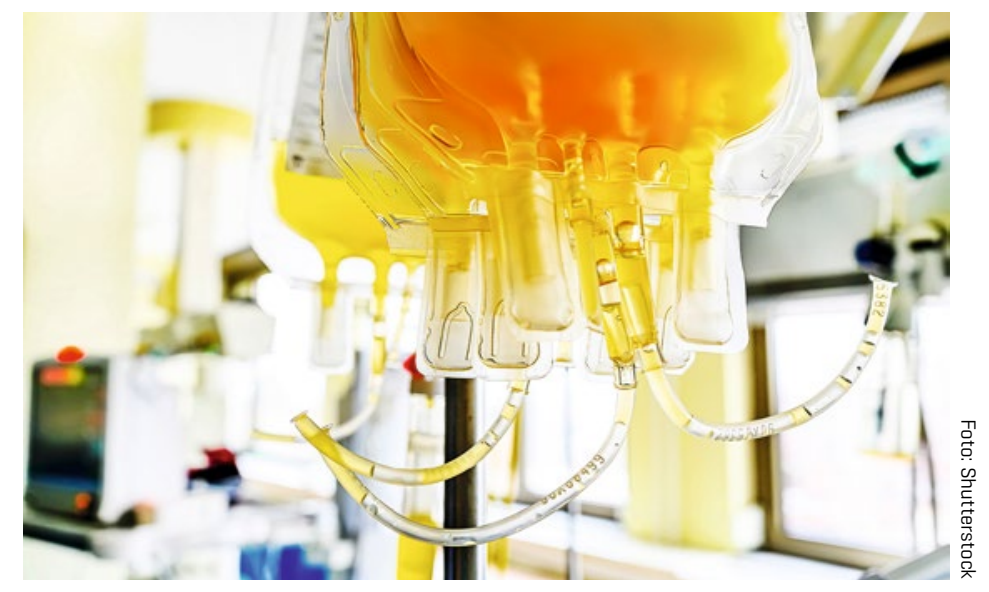

huizen volgen op korte termijn (www.coronaplasmastudie.nl). In afwachting daarvan kunnen patiënten van heel Nederland in de al opgestarte ziekenhuizen terecht.

Om de effectiviteit van de plasma-antistofbehandeling zo snel mogelijk te bewijzen, is de inclusie van 660 (!) patiënten $<6$ maanden noodzakelijk.

Patiënten die $<8$ dagen ziek zijn en bewezen SARS-CoV-2 positief zijn, komen in aanmerking als ze voldoen aan de criteria uit het addendum [kader]. Huisartsen kunnen patiënten van 50 jaar of ouder dus op het onderzoek wijzen. De patiënt kan op de website zelf nagaan of hij in aanmerking komt en zich zo nodig aanmelden. Daarna nemen de onderzoekers contact op met de patiënt.

De resultaten zullen bij voldoende instroom van patiënten in de loop van 2021 bekend worden.

\section{LITERATUUR}

1. Gharbharan A, et al. Convalescent plasma for COVID-19. A randomized clinical trial. Med Rxiv 2020;07.0120139857. https:// www.medrxiv.org.

2. Pathak EB. Convalescent plasma is ineffective for covid-19. BMJ 2020;371:m4072. https://www.bmj.com.

3. Ventura A, et al. A randomized trial of convalescent plasma in covid-19 severe pneumonia. N Engl J Med 2020; November 24. https://www.nejm.org.

4. U.S. Food \& Drug Administration. Coronavirus (COVID-19) Update: FDA authorizes monoclonal antibodies for treatment of COVID-19. Silver Spring: FDA, 2020. https://www.fda.gov.

Rijnders BJA. Nieuw onderzoek naar plasma-antistofbehandeling voor niet-opgenomen COVID-19-patiënten. Huisarts Wet 2020;63:D0I:10.1007/s12445020-1017-7.

Erasmus MC, Rotterdam: B.J.A. Rijnders, internist-infectioloog en projectleider CoV-Early-studie, b.rijnders@erasmusmc.nl.

Mogelijke belangenverstrengeling: niets aangegeven.

Dit is een bijdrage in de rubriek Lopend onderzoek, relevant voor de eerste lijn. 


\section{ADDENDUM}

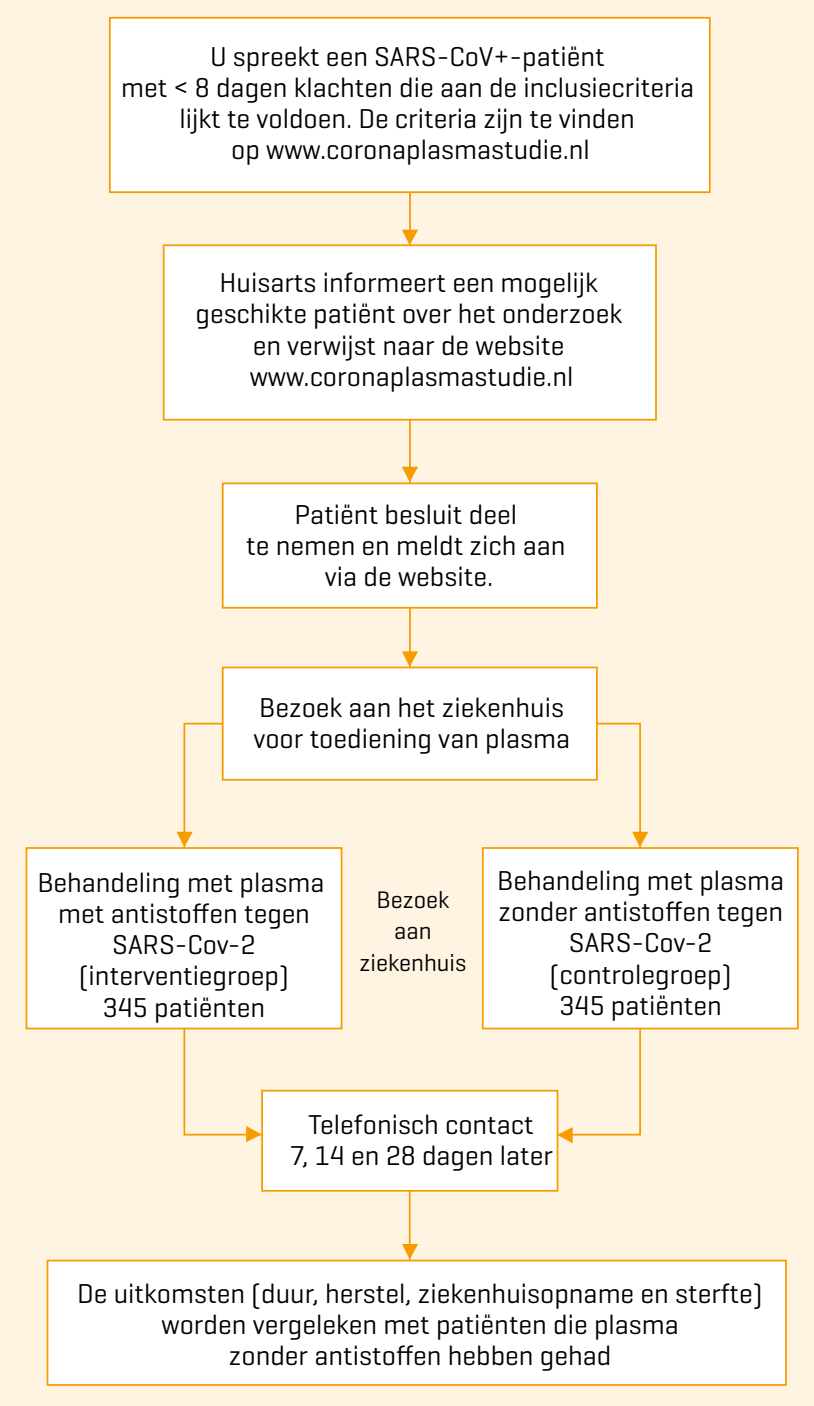

\section{Wie kan deelnemen?}

Patiënten met $<8$ dagen symptomen [welk symptoom dan ook] die positief testen op SARS-CoV- 2 en in 1 van de onderstaande risicogroepen vallen.

- Patiënten van 70 jaar of ouder.

- Patiënten van 50 tot 69 jaar met daarenboven een additionele risicofactor, zoals diabetes, hart-en vaatziekte, chronische long -of leverziekte, systemische behandeling voor kanker in de voorbije 12 maanden, een BMI van 35 of meer, nierinsufficiëntie [GFR $<60 \mathrm{ml} / \mathrm{min}$ ]. Deze criteria kunnen tijdens het verloop van het onderzoek veranderen. Kijk daarom voor de volledige en actuele lijst aan criteria voor deze leeftijdsgroep op www.coronaplasmastudie.nl.

- ledereen van 18 tot 49 die ernstig immuungecompromitteerd is. Overleg voor deze specifieke patiëntengroep altijd met het onderzoeksteam.

Op de website is ook de officiële vertaling naar het Arabisch en Engels van het Nederlandse informed consentformulier te vinden. Daarnaast zijn er filmpjes beschikbaar in het Nederlands, Engels en Arabisch waarin het onderzoek in 5 minuten wordt uitgelegd. 